\title{
Physical activities, sports and sustainability: a reflection on the role of the world surf league
}

\author{
Atividades físicas, esportes e sustentabilidade: uma reflexão sobre o papel da liga mundial de surfe \\ Actividades físicas, deporte y sostenibilidad: una reflexión sobre el papel de la liga mundial de surf
}

\author{
Tiago Brant de Carvalho FalCão ${ }^{1}$; RICARdo RiCCI UVINHA ${ }^{2}$ \\ Universidade de São Paulo, USP, São Paulo-SP, Brasil
}

\begin{abstract}
Sustainability and nature preservation are part of the surfer's lifestyle and could influence the new generations as a way to reverse the actual climate and environmental crisis that the planet is going through. The World Surf League (WSL), attentive to the wishes of its community, has been working on communication strategies to spread good intentions and sustainable initiatives as a way of leading a movement in defense of the seas and its desired waves. This manuscript intends to do case studies and a literature review to understand this movement. Above all, it is an example to other organizations and a way of spreading the positive messages that surfing can deliver to the contemporary world, thus playing an essential role in planetary peace and sustainability.
\end{abstract}

Keywords: Water Sports. Surfing. Lifestyle. Sustainability.

\section{RESUMO}

Sustentabilidade e preservação da natureza fazem parte do estilo de vida do surfista e podem influenciar as novas gerações de forma a reverter a atual crise climática e ambiental pela qual passa o planeta. A World Surf League (WSL), atenta aos desejos de sua comunidade, vem trabalhando em estratégias de comunicação para difundir boas intenções e iniciativas sustentáveis, como forma de liderar um movimento em defesa dos mares e de suas desejadas ondas. Este manuscrito pretende fazer estudos de caso e uma revisão de literatura para entender esse movimento. Acima de tudo, é um exemplo para outras organizações e uma maneira de espalhar as mensagens positivas que o surf pode transmitir ao mundo contemporâneo, desempenhando, assim, um papel essencial na paz e sustentabilidade planetárias.

Palavras-chave: Esportes Aquáticos. Surf. Estilo de vida. Sustentabilidade.

\section{RESUMEN}

La sostenibilidad y la preservación de la naturaleza son parte del estilo de vida del surfista y podrían influir en las nuevas generaciones como una forma de revertir la crisis climática y ambiental que atraviesa el planeta. La World Surf League (WSL), atenta a los deseos de su comunidad, ha estado trabajando en estrategias de comunicación para difundir buenas intenciones e iniciativas sostenibles como una forma de liderar un movimiento en defensa de los mares y sus olas deseadas. Este manuscrito tiene la intención de hacer estudios de casos y una revisión de la literatura para comprender este movimiento. Sobre todo, es un ejemplo para otras organizaciones y una forma de difundir los mensajes positivos que el surf puede entregar al mundo contemporáneo, desempeñando así un papel esencial en la paz y la sostenibilidad planetarias.

Palabras clave: Deportes Acuáticos. Surf. Estilo de vida. Sostenibilidad.

\footnotetext{
1 Member of the Interdisciplinary Group of Leisure Studies/University of Sao Paulo. E-mail: tiagobfalcao@gmail.com

${ }^{2}$ Full Professor and Vice Dean, School of Arts, Sciences and Humanities, Leader of the Interdisciplinary Group of Leisure Studies, University of Sao Paulo. E-mail: uvinha@usp.br
} 


\section{INTRODUCTION}

The Olympics Games Tokyo - 2020 will mark the rise of surfing to the Olympic pantheon. Kampion (2003) argues that surfing was revealed to Western civilization in 1778 by British Royal Navy Captain James Cook, as his crew crossed the northern Pacific Ocean on the way back to Europe. The first impression, as he saw natives surfing naked on wooden boards, is described by Cook: "It was impossible not to conclude that this man felt the supreme pleasure as he was guided so swiftly and so gently by the sea". It was only in the early twentieth century, through swimmer and Olympic champion Duke Kahanamoku, that the world heard of surfing again. A gold medalist in the 100m freestyle in Stockholm (1912) and Belgium (1920), Duke participated in three Olympic editions and won five medals: Stockholm 1912 (gold in $100 \mathrm{~m}$ freestyle and silver in the 4x200m freestyle); Antwerp 1920 (gold in the $100 \mathrm{~m}$ freestyle and gold in the 4x200m freestyle); Paris 1924 (silver in the $100 \mathrm{~m}$ freestyle). Following the fame of his Olympic domination, Duke Kahanamoku became the world surfing ambassador, spreading the practice that, as he justified, was the source of his athletic performance. He made demonstrations in the United States (California - 1912) and also in Australia (1914), widely spreading surfing in these places. Later on, during the 1970s and 1980s, surfing became global, as a result of a strong "cultural revolution", according to Eric Hobsbawn (1995), triggered by an emerging youth culture.

Young culture became the matrix of the cultural revolution, in the broadest sense, of a revolution in manners and customs, in the means of enjoying leisure and in the commercial arts, which increasingly formed the atmosphere breathed by urban men and women (HOBSBAWN, 1995, p. 323).

The phenomenon of the appearance and growth of surfing and other action sports in the world corresponds to the period of history known as postmodernity, which began in the middle of the twentieth century. It became commonplace to speak of our time as that of fast pace, almost relegating to oblivion a time not too distant, in which life seemed like an unhurried walk on safe trails. To understand the high speed of our time it's necessary to observe the contemporary society. Compared to the culture of the nineteenth and part of the twentieth century, ours has subverted old ways of life. The new styles feed on continuous technological and scientific innovations and also on socio-cultural values and patterns inspired by the affirmation of new identities. Thus, the discontinuity of traditions is an essential mark of postmodernity. "[...] the historical cycle in which we find ourselves is wholly taken up by accelerated, uninterrupted and cumulative change. In it, technological innovations and sociocultural modifications that permeate all the plans and sectors of social life are intertwined" (NOGUEIRA, 1995, p. 107).

There is no single expression to designate our time and the societies in it. Postmodernity, late modernity, control society, the society of the norm and net society are some of the designations attributed to it by contemporary scholars. We live in a complex and multifaceted culture. A global community that, on the one hand, keeps its citizens strongly interconnected and, on the other hand, extremely vulnerable in its relational ties of inclusion and belonging.

The emergence of individuality signalled a progressive weakening, disintegration or destruction of the dense network of social bonds that tightly tied the whole of life's activities. It also pointed out that the community was losing the power - and/or interest - to normatively regulate the lives of its members (BAUMAN, 2007, p. 31). 
In postmodernity, the individual becomes the reference itself. In this context, the present and not the future, the immediate rather than the mediate, became the meaning of individual projects, of particular groups, of minorities and not of collective ones expressed in social classes, in the majorities. Political action is therefore tainted by the fragmentation of interests. Through various identity micro-groups, civil society places in the background the traditional channels of representation and mediation of collective interests (parties, parliaments, unions). It is in this vein that emerge the movements of ecological defense, minority defense and consumer protection, among others, that express plural, but fragmented and particular characteristics, proper of the contemporary society. The same movement happens in the media, making society replace, at first slowly and later, in an accelerated way, traditional media channels (e.g. newspapers, magazines, television and radio). This process has happened in all directions and stakeholders, transforming what was a publisher/public relationship, to a digital, multidirectional and shareable model made possible by the Internet, as are the so-called social media (SHIRKY, 2011). Today, everything is instantaneous and totalitarian unanimity is no longer a possibility, opening space for an infinite diversity of styles and preferences, bringing to light niche cultures once relegated to a lower plane, such as surfing.

Along with its young lifestyle, surfing grew competitively since the creation of the world surfing circuit by two Hawaiian surfers, Randy Harrick and Fred Hammings, in 1976, when they instituted IPS, International Professional Surfers, and also in the following decades, under the tutelage of ASP, Association of Surfing Professionals (1982 to 2014), founded by Australian Ian Cairns. In that period, the Australians won 20 world titles, while the North Americans won 19, including the eleven world titles won by the greatest champion in history, Kelly Slater. In 2014 ASP was purchased by the media company ZoSea to turn it into WSL, World Surf League.

Surfing has reached maturity in various aspects, such as the organization of national and international leagues, high performance and professionalism, accrediting the practice to the highest spheres of world sport, such as the Olympic Games. Combining the desire for youth and the widespread appeal, the IOC is seeking the media repercussion that can generate even more advertising profits for the organization, as well as an engaged public. Through the media, sport becomes spectacle, entertainment and also information, as well demonstrates the acquisition of ASP by a media company, ZoSea Media HoldingsInc., to transform an association of professional surfers (ASP) into a worldwide league of surfing (WSL), aiming for a more attractive, perennial and close communication to the general public, transforming athletes into idols in a society lacking good references.

Sometimes the senses of the sport are made up of the athlete who, as a hero or demigod, is a source of inspiration. One can see a sincere veneration for the figure of the sportsman who, because they have stood out in their respective modalities, become the object of attention (TAMBUCCI, 2011, p. 669).

Thinking about those issues, WSL rapidly promoted a change in its ways of communicating and generate fandom trough events and media products. The surfing world tour came to be broadcasted live from all its paradisiacal addresses, via streaming, while short programs of video content have come to dominate the landscape of their website, as well as their social media, promoting surfing's lifestyle and the 
sustainable practices it embraces.

Sustainability and nature preservation are part of the surfer's lifestyle and it can influence the general public as a way to reverse the actual climate and environmental crisis that the planet is going through. With that aspect in mind, WSL, always attentive to the wishes of its community, has been working on communication strategies to spread good intentions and sustainable initiatives as a way of leading a movement in defense of the seas and its wishful waves. The organization understands that communication is at the base of a strategy that seeks to attract new fans for the sport and its respective market, bringing along entities committed to solutions for ecological demands such as Sustainable Surf, Earth Technologies, The Plastic Pickup, Counter Current Art and The Cigarette Surfboard. Each stakeholder contributes to our current environmental crisis through art, storytelling, and sustainable design.

In addition to legitimizing and publicizing these initiatives, WSL has its ideas in this regard, such as the \#stoptrashingwaves campaign and WSL Pure ${ }^{3}$ that underpin the entity's commitment on promoting practices to reduce the environmental impact caused by their events. The organization aims to become carbon neutral by the end of 2019 , cutting out single-serve plastic, as well as cleaning and restoring the beaches trough where it passes. Doing so, it enhances the experience for the viewer and gives more value to the act of surfing or watching the sport. Above all, it is an example to other organizations and a way of spreading the positive messages that surfing can deliver to the contemporary world, thus playing an essential role for planetary sustainability.

\section{METHODOLOGY}

This paper is based on case studies and a literature review to understand WSL's strategy regarding the environment they depend on to promote surfing. Considering the case study method, there should always be a concern to understand what the case suggests about the whole and not the study of just that case (VENTURA, 2007) and all of the case studies mentioned in this work have to do with responsible practices for sustainability. For Chizzotti (2006), the case study as a research modality originates from Malinowski's anthropological studies and the Chicago School, subsequently being expanded to study actions, events, processes, organizations, groups, communities, and so on. Therefore, this research method involves making choices and, in each particular case, there must be a certain level of aggregation. Thus, one can analyze the case to identify its most relevant components or assign them to relative degrees of importance depending on the specific case. The literature review is always useful to make comparisons with other similar cases, seek theoretical foundation and also to strengthen the arguments of those who are describing the case. According to Stake (2000), a case study is characterized by the interest in individual cases and not by research methods that it can cover. This author points out that "[...] not everything can be considered a case" (p. 436) because a case is "[...] a specific unit, a delimited system whose parts are integrated" (p. 436). The case study as a research modality is understood as a methodology and as the choice of a study object defined by an interest in individual cases. It aims to investigate a specific case, well delimited, contextualized in time and place so that a detailed search for information can be performed (VENTURA, 2007).

\footnotetext{
${ }^{3}$ www.worldsurfleague.com/pure
} 


\section{RESULTS \& DISCUSSION}

During the Freshwater Pro 2019, second event of the world circuit of surfing to be held on the artificial waves of Surf Ranch, 100 miles away from the coastline at Leemore in the US state of California, held from 19 to 21 September 2019, WSL set up a promotional space for the exhibition of initiatives aimed at sustainability of the oceans called WSL Pure Village. The following cases cited were part of the exhibition and deserve our attention in this case study.

\section{SUSTAINABLE SURF}

One of the biggest problems for surfing sustainability is the making of surfboards. Since the 1950s, with the introduction of polyurethane blocks and resin fabrics, both chemical derivatives of petroleum, an ultimate symbol of the sport, the surfboard, has become unsustainable. That is why today's scientists and board manufacturers have been trying to reduce the carbon footprint of building surfboards. In 2012, an environmental quality seal for surfboards was created with the support of major surfboard brands such as Firewire and Channel Islands Surfboards called Ecoboard. All Ecoboard project recommendations are based on a life cycle study of these products:

a) Resin represents $40 \%$ of a board's carbon footprint.

The best way to reduce the impact of the resin itself is to switch to a plantbased resin. Most surfboard resins are highly processed petrochemicals with a significant carbon footprint. By displacing some of this petroleum with plant-derived elements, the carbon footprint can be reduced ${ }^{4}$.

b) Polyurethane Block represents about $10 \%$ of a board's carbon footprint.

Like resin, most foam cores are made from highly processed petrochemicals, and thus have a high carbon footprint. Using recycled or plant-based content can reduce the carbon footprint of the blank. Currently, only Marko Foam 25\% recycled EPS Envirofoam blanks have been approved as Qualified Materials. Arctic Foam is presently developing an algae-based polyurethane blank. Testing is yet to be completed regarding the bio-content of this material $^{5}$.

c) Fiberglass represents $2 \%$ of a board's carbon footprint.

Fiber cloth as used in a typical surfboard has a tiny contribution to the footprint of a surfboard. Also, it seems that even the most innovative board builders still need a small amount of fiberglass to produce a high-quality finish on the board. So, we do not currently require alternatives to fiberglass in our ECOBOARD Benchmark ${ }^{6}$.

\section{EARTH TECHNOLOGIES}

In traditional surfboard manufacturing, there is approximately twice the weight of the finished board in waste (or garbage) generated in the production process. This consists of fiberglass fabric waste materials or technical materials such as masking tape, resin, stirring sticks, foam dust, sandpaper and more. Even if a surfer loves to surf, this

\footnotetext{
${ }^{4}$ http://www.sustainablesurf.org/ecoboard/ecoboard-resource-guide/

5 http://www.sustainablesurf.org/ecoboard/ecoboard-resource-guide/

6 http://www.sustainablesurf.org/ecoboard/ecoboard-resource-guide/
} 
situation is more wasteful than he would like to accept.

So, we've been developing the world's first Zero Waste Manufacturing system to eliminate all of that waste we generate during production. We sort our waste as we go during production to consume it via two channels - first, our super mealworms, and second, our Greenlines Zero Waste products. We purposefully keep our drip trays covered with trash. This allows the waste to saturate with resin that falls off boards during production, and once it is hard enough we run this waste through our high-density shredder ${ }^{7}$.

\title{
THE PLASTIC PICKUP
}

It was the spring of 2016 when Alex Weber and her father, Mike Weber, noticed hundreds of golf balls underwater, as they were free diving in the shallow waters adjacent to the Pebble Beach golf course, in central coast California, close to their home. One year after what started out as a game, Alex decided to pursue a scientific research under the mentorship of Matthew Savoca, a postdoctoral researcher at Hopkins Marine Station of Stanford University, to report that less known source of debris to the marine environment: golf balls. From May 2016 to June 2018, her team made 75 collections and recovered 39,602 balls from intertidal and nearshore habitats adjacent to, or downriver from, the golf courses of Carmel, California. Combining their collections with concurrent efforts of the Monterey Bay National Marine Sanctuary and the Pebble Beach Corporation, they reported the retrieval of 50,681 balls, totalling approximately 2.5 tons of debris (WEBER; WEBER; SAVOCA, 2019).

\begin{abstract}
After observing the collected 40,000 golf balls, we recognized evidence of physical, and biological degradation. In seawater golf balls are slightly negatively buoyant, which causes them to be easily displaced and tumbled underwater and in the surf zone. The oceans movement via tides, swells, and currents is responsible for wearing the synthetic materials off a golf ball and into the ocean. Essentially the ocean acts as a massive rock tumbler, which causes the golf balls to slowly wear down over time. The byproduct of this degradation is a tiny micro plastic released into the ocean off the surface of the golf balls ${ }^{8}$.
\end{abstract}

\section{COUNTER CURRENT ART}

A self-titled collective of artists called Counter Current Art, represented by artist and environmental activist Ethan Estess, teamed up with Alex Weber to produce an art object designed to denounce and discuss the rubbish represented by golf balls collected at sea, in the form of a wave that received the name of "Marine Debris Golf Ball Sculpture". This sculpture was exhibited and used at the PURE VILLAGE during Freshwater Pro at Surf Ranch, drawing public attention to the problem of golf balls in the sea.

Countercurrent is collaborating with the Plastic Pick-Up to create a largescale interactive wave sculpture from over 20,000 golf balls collected from the ocean. We fabricated the sculpture from steel and assembled it securely on a $26 \mathrm{ft}$ flatbed trailer for easy transport to events around the country. Our goal is to use marine debris golf balls as a conversation starter to engage

\footnotetext{
${ }^{7}$ https://earthtechsurf.com/pages/zero-waste-greenlines

8 https://www.theplasticpick-up.org/golf-ball-break-down
} 
viewers in a broader dialogue around personal/corporate responsibility to combat ocean plastic pollution?

\section{THE CIGARETTE SURFBOARD}

The idea of the Cigarette Surfboard, a surfboard made with cigarette butts, was done for an international competition held by the surf company Vissla, in collaboration with the Surfrider Foundation. The goal of that contest was simple: to create an article of surf-craft out of upcycled materials. The artists saw this as an opportunity to address a significant issue that surfers experience daily: beach and ocean pollution, with the use of seemingly harmless cigarette butts.

Cigarette butts are the most littered item in the world (5.6 trillion a year). The butts are made of plastic (cellulose acetate) which means they will never fully decompose. Not to mention, each butt contains thousands of toxic chemicals that leach into the environment ${ }^{10}$.

In a way to call attention to this hazardous fact, "[...] industrial designer Taylor Lane and filmmaker Ben Judkins are creating an environmental surf film that uses the Cigarette Surfboards to question the mentality of littering cigarette butts, and how this largely represents our single-use plastic culture and its effects on the ocean"11.

\section{About Plastic Pollution}

Nature and, in particular, the ocean, have been undergoing gradual degradation since the 1900s, due to habits and products characteristic of modernity, such as plastic, which, since it is not biodegradable, can persist for centuries in the environment, causing an accumulation of unprecedented synthetic pollution that threatens nature sports and, worse, life as we know it on the planet. There are currently more than five trillion pieces of plastic in the sea, together weighing over a quarter of a million tons (ERIKSEN et al., 2014). The vast majority of plastic waste originates on land, reaches rivers and enters the ocean at a rate of 8 to 12 million tons per year (JAMBECK et al., 2015; LEBRETON et al., 2017). Such pollution is globally distributed across all oceans due to the material's long durability and buoyancy properties which, added to the high uptake of toxics by plastic during its travel across the oceans (TEUTEN et al., 2007; MATO et al., 2001), leads researchers to state that synthetic polymers present in oceans should be considered hazardous waste (ROCHMAN et al., 2013). Through photodegradation and other weathering processes, plastics fragment and disperse into the sea (BARNES et al., 2009), converging not only on subtropical gyres (LAW et al., 2010), but also on the full extent and depth of the oceans. Plastic pollution generation and accumulation also occur in large quantities in enclosed bays, gulfs, and seas surrounded by densely populated coasts and watersheds (REISSER et al., 2013; RYAN, 2013).

The impact of pollution is not only due to the accumulation of plastic waste in natural environments but also through ingestion and entanglement of marine fauna, ranging from zooplankton to large cetaceans, birds and marine reptiles (GREGORY, 2009). Adsorption of organic pollutants present in plastic and their transfer to tissues and organs by ingestion (TEUTEN et al., 2009) is affecting marine megafauna

\footnotetext{
${ }^{9} \mathrm{http}: / / \mathrm{www}$. countercurrentart.org

${ }^{10} \mathrm{https}: / / \mathrm{www}$. thecigarettesurfboard.com/backstory

11 https://www.thecigarettesurfboard.com/
} 
(TANAKA et al., 2013) as well as lower trophic level organisms (BAKIR; ROWLAND; THOMPSON, 2014) and their predators (SETÄLÄ; FLEMINGLEHTINIEN; LEHTINIEMI, 2014). These impacts are further compounded by the persistence of floating plastics, ranging from resin pellets to largely abandoned nets, docks and boats that float across oceans and carry microbial communities (CARSON et al., 2013), algae, invertebrates and fish (GOLDSTEIN; CARSON; ERIKSEN, 2014) for non-native regions (BARNES, 2002), adding more justifications for monitoring (and taking measures to mitigate) the global abundance of plastic pollution. While knowing that the resolution of this global environmental problem is complex and growing, WSL understands that part of the problem is cultural and relies on urgent ecological education so that small actions by a large number of individuals can gradually change the perverse reality in which we live. In this sense, the organization supports and disseminates environmental initiatives that can and should improve this scenario in the long term, so that the much-vaunted prediction of more plastic than fish in the ocean by 2050 (NG, 2018) will not be realized.

\section{WSL COMMITMENTS}

As part of the WSL PURE campaign, the organization made three commitments to its audience:

- Cut out single-serve plastics from its events by the end of 2019, since studies have proven that:

a) Plastics break down into small microparticles that are ingested by marine life, ultimately entering the food we eat and water we drink (VAN SEBILLE et al., 2015).

b) 4 to 10 million metric tons of plastic end up in the ocean each year (CHEN, 2015).

c) A third of all fish caught in the UK and $83 \%$ of drinking water samples from around the world are contaminated with microplastic (JOHNSON, 2017).

The use of plastics is widespread and while recycling helps, most plastic still ends up outside of the recycling system. Plastic pollutes our beaches and affects wildlife and humans through the water we recreate in and the seafood we eat. In light of this, the WSL pledges to eliminate single-serve plastics from WSL Championship Tour and Big Wave Tour events by the end of $2019^{12}$.

- Becoming Carbon Neutral by the end of 2019 is another commitment made by WSL, assuming that the entity runs different world tours of surfing events, which presupposes the duty to fly hundreds of people across five continents, leaving a substantial carbon footprint on the planet. "That's why we're reinvesting the cost of our tour's carbon footprint into projects that safeguard marine life" ${ }^{\prime 3}$.

Oceans makeup over $70 \%$ of the earth's surface and are responsible for: regulating our global climate, providing us with the food we depend on for survival, and cleaning the air we breathe. Our one ocean is also the world's largest storehouse for carbon with more than $80 \%$ of the carbon cycle circulating through the waves we ride ${ }^{14}$.

\footnotetext{
${ }^{12}$ https://www.worldsurfleague.com/posts/379084/wsl-pure-plastic

13 www.worldsurfleague.com/pure

14 https://www.worldsurfleague.com/posts/379080/wsl-pure-climate
} 
- The third commitment made by WSL is to restore the coasts by leaving every beach better than it has found it: picking up trash on its trails; avoid walking over dunes and stepping on beachgrass (beachgrass helps keep the dunes in place); wearing reefsafe sunblock; respecting the local ecosystem by always staying on pathways (following local rules and signage protects sensitive habitats); donating to organizations on the ground working to make a positive impact.

\begin{abstract}
We host events all over the world in some of the most beautiful places and with some of the strongest communities on the planet. We know that healthy coasts are better for everyone, but we've also seen the impacts of overuse, development and habitat loss. From trampling over sand dunes, to sunscreen bleaching reefs, wherever we travel, humans leave their mark and our coastal communities are continually feeling this pressure. To protect our one shared ocean, we need to safeguard its surrounding land ${ }^{15}$.
\end{abstract}

\title{
CLOSING REMARKS
}

Through the practice of surfing and other adventure sports related to nature, human beings establish intense relationships with themselves, with the elements of nature and also with their peers in the social process that results from the experience. There is a connection with the biosphere, promoting the inclusion of the human being in the planetary ecosystem and bringing the sense of belonging to the cosmos. In addition to the school-stimulated cognitive development, it is essential to offer the child and adolescent the practice of outdoor sports as part of their education for life. Although not valued in this respect, nature-related sports and surfing, for example, are great instruments for the promotion of physical and mental health, especially in socially vulnerable populations, without access to basic health and education conditions, as we observe on a large scale in the modern world.

\begin{abstract}
Although adventure, as a subjective experience of the search for emotions in front of the unusual, is perhaps an anthropological constant, it is in the contemporary times that one experiences a diversification of adventure activities, from the perspective of leisure. In theory, they are linked to sensations of risk and vertigo, controlled exacerbations of emotions and, in many cases, gratitude to nature and other sensitive dimensions, whose search for revaluation points to a differential of these practices concerning to conventional sports (PIMENTEL, 2013, p. 688).
\end{abstract}

The positive influence of surfing brought by communication tactics can do so much for sustainability. Promoting a modern and popular sports related to nature, such as surfing, in a mega-sport event such as the Olympic Games is another critical aspect for the growth of its audience, the promotion of its lifestyle and the sustainable practices it embraces. In times of global warming and rampant pollution, endangering life in this environment, surfing can promote an environmental reconnection and remind the public of the paramount importance of nature in their daily lives and practices on building a better future for the planet.

${ }^{15}$ https://www.worldsurfleague.com/posts/379089/wsl-pure-coasts 


\section{REFERENCES}

BAKIR, A.; ROWLAND, S.; THOMPSON, R. Enhanced desorption of persistent organic pollutants from microplastics under simulated physiological conditions. Environ Pollut, v. 185, p. 16-23, 2014.

BARNES, D. Invasions by marine life on plastic debris. Nature, v. 416, p. 808-809, 2002.

BARNES, D.; GALGANI, F.; THOMPSON, R.; BARLAZ, M. Accumulation and fragmentation of plastic debris in global environments. Philos Trans R Soc Lond B Biol Sci, v. 364, p. 1985-1998, 2009.

BAUMAN, Z. Modernidade Líquida. Rio de Janeiro: Jorge Zahar Ed., 2007.

CARSON, H.; NERHEIM, M.; CARROLL, K.; ERIKSEN, M. The plastic-associated microorganisms of the North Pacific Gyre. Mar Pollut Bull, v. 75, p. 126-132, 2013.

CHEN, A. Here's how much plastic enters the ocean each year. Science, Feb. 12, 2015. Disponível em:<https://www.sciencemag.org/news/2015/02/here-s-how-much-plastic-enters-ocean-each-year>.

Acesso em: 21 nov. 2019.

CHIZZOTTI, A. Pesquisa qualitativa em ciências humanas e sociais. Petrópolis: Vozes, 2006.

ERIKSEN, M.; LEBRETON, L. C. M.; CARSON, H. S.; THIEL, M.; MOORE, C. J.; BORERRO, J. C.; GALGANI, F.; RYAN, P. G.; REISSER, J. Plastic Pollution in the World's Oceans: More than 5 Trillion Plastic Pieces Weighing over 250,000 Tons Afloat at Sea. PLoS ONE, v. 9, n. 12, p. e111913, 2014.

GOLDSTEIN, M.; CARSON, H.; ERIKSEN, M. Relationship of diversity and habitat area in North Pacific plastic-associated rafting communities. Marine Biology, 2014. Doi: https://doi.org/10.1007/s00227-014-2432-8.

GREGORY, M. Environmental implications of plastic debris in marine settings-entanglement, ingestion, smothering, hangers-on, hitch-hiking and alien invasions. Philosophical Transactions of the Royal Society B: Biological Sciences, v. 364, p. 2013-2025, 2009.

HOBSBAWN E. Era dos extremos: o breve século XX. São Paulo: Companhia das Letras, 1995.

JAMBECK, J. R.; GEYER, R.; WILCOX, C.; SIEGLER, T. R.; PERRYMAN, M.; ANDRADY, A.; NARAYAN, R.; LAW, K. L. Plastic waste inputs from land into the ocean. Science, v. 347, p. 768-771, 2015.

JOHNSON, A. E. We Need to Kick our Addiction to Plastic. Scientific American, Oct. 2017. Disponível em: $\quad\langle$ https://blogs.scientificamerican.com/observations/we-need-to-kick-our-addiction-to-plastic/>. Acesso em: 21/11/2019.

KAMPION, D. Stoked! A history of surf culture. Salt Lake City: Gibbs Smith, 2003.

LAW, K. L.; MORÉT-FERGUSON, S.; MAXIMENKO, N. A.; PROSKUROWSKI, G.; PEACOCK, E. E.; HAFNER, J.; REDDY, C. M. Plastic accumulation in the North Atlantic Subtropical Gyre. Science, v. 329 , p. $1185-1188,2010$.

LEBRETON, L. C. N.; VAN DER ZWET, J., DAMSTEEG, J. W.; SLAT, B.; ANDRADY, A.; REISSER, J. River plastic emissions to the world's oceans. Nature Communications, v. 8, p. 15611, 2017.

MATO, Y.; ISOBE, T.; TAKADA, H.; KANEHIRO, H.; OHTAKE, C.; KAMINUMA, T. Plastic resin pellets as a transport medium for toxic chemicals in the marine environment. Environ Sci Technol, v. 35 p. 318-324, 2001.

NG, C. W. A Plastic Tide: Mining floating plastic waste through landscape processes Landscape Architecture Frontiers, v. 6, n. 4, p. 126-135, 2018. 
Tiago Brant de Carvalho Falcão; Ricardo Ricci Uvinha

NOGUEIRA, M. A. Para uma governabilidade democrática progressiva. Lua Nova, n. 36, p. 105-128, 1995.

PIMENTEL, G. G. A. Sports in Nature and Adventure Activities: An Aphromatic Terminology. Rev. Bras. Ciênc. Esporte, v. 35, n. 3, p. 687-700, jul./set. 2013.

REISSER, J.; SHAW, J.; WILCOX, C.; HARDESTY, B. D.; PROIETTI, M.; THUMS, M.; PATTIARATCHI, C. Marine plastic pollution in the waters around Australia: Characteristics, concentrations and pathways. PLoS ONE, v. 8, n. 11, p. e80466, 2013.

ROCHMAN, C. M.; BROWNE, M. A.; HALPERN, B. S.; HENTSCHEL, B. T.; HOH, E.; KARAPANAGIOTI, H. K.; RIOS-MENDOZA, L. M.; TAKADA, H.; THE, S.; THOMPSON, R. C. Classify plastic waste as hazardous. Nature, v. 494, p.169-171, 2013.

RYAN, P. A simple technique for counting marine debris at sea reveals steep litter gradients between the Straits of Malacca and the Bay of Bengal. Mar Pollut Bull, v. 69, p. 128-126, 2013.

SETÄLÄ, O.; FLEMING-LEHTINEN, V.; LEHTINIEMI, M. Ingestion and transfer of microplastics in the planktonic food web. Environ Pollut, v. 185, p.77-83, 2014.

SHIRKY, C. A cultura da participação. Rio de Janeiro: Zahar, 2011.

STAKE. R. E. Case studies. In: DENZIN, N. K.; LINCOLN, Y. S. (Ed.). Handbook of qualitative research. London: Sage, 2000. p. 435-454.

TAMBUCCI, P. L. Marketing Esportivo In: HIGUCHI, M. Gestão de Marketing e Comunicação: avanços e aplicações. São Paulo: Saraiva, 2011.

TANAKA, K.; TAKADA, H.; YAMASHITA, R.; MIZUKAWA, K.; FUKUWAKA, M. A.; WATANUKI, Y. Accumulation of plastic-derived chemicals in tissues of seabirds ingesting marine plastics. Mar Pollut Bull, v. 69, p.219-222, 2013.

TEUTEN, E. L.; SAQUING, J. M.; KNAPPE, D. R. U.; BARLAZ, M. A.; JONSSON, S.; BJÖRN, A.; ROWLAND, S. J.; THOMPSON, R. C.; GALLOWAY, T. S.; YAMASHITA, R.; OCHI, D.; WATANUKI, Y.; MOORE, C.; VIET, P. H.; TANA, T. S.; PRUDENTE, M.; BOONYATUMANOND, R.; ZAKARIA, M. P.; AKKHAVONG, K.; OGATA, Y.; HIRAI, H.; IWASA, S.; MIZUKAWA, K.; HAGINO, Y.; IMAMURA, A.; SAHA, M.; TAKADA, H. Transport and release of chemicals from plastics to the environment and to wildlife. Philosophical Transactions of the Royal Society B: Biological Sciences, v. 364, p. 2027-2045, 2009.

TEUTEN, E.; ROWLAND, S.; GALLOWAYT, T.; THOMPSON, R. Potential for plastics to transport hydrophobic contaminants. Environ Sci Technol, v. 41, p. 7759-7764, 2007.

VAN SEBILLE, E.; WILCOX, C.; LEBRETON, L.; MAXIMENKO, N.; HARDESTY, B. D.; VAN FRANEKER, J. A.; ERIKSEN, M.; SIEGEL, D.; GALGANI, F.; LAW, K. L. A global inventory of small floating plastic debris. IOP Science, v.10, p. 1-11, 2015.

VENTURA, M. V. The Case Study as a Research Mode. Rev SOCERJ, v. 20, n. 5, p. 383-386, 2007.

WEBER, A. K.; WEBER, W. W.; SAVOCA M. S. Quantifying marine debris associated with coastal golf courses. Marine Pollution Bulletin, v. 140, p. 1-8, 2019.

Received: Nov. 21, 2019.

Approved: Dec. 07, 2019. 